Отримано: 9 лютого 2019 р.

Прорецензовано: 25 лютого 2019 р.

Прийнято до друку: 1 березня 2019 р. e-mail: smal.oksana85@gmail.com

DOI: $10.25264 / 2519-2558-2019-5(73)-199-201$
Смаль О. В., Яновець А. І., Літкович Ю. В. Використання новітніх технологій у процесі навчання майбутніх філологів. Наукові записки Наиіонального університету «Острозька академія»: серія «Філологія». Острог: Вид-во НаУОА, 2019. Вип. 5(73), березень. С. 199-201.

\author{
Смаль Оксана Вімалї̈вна, \\ кандидат філологічних наук, завідувач кафедри української та іноземної лінгвістики, \\ Луцьький національний технічний університет \\ Яновець Анжеліка Іванівна, \\ кандидат філологічних наук, доцент кафедри української та іноземної лінгвістики, \\ Луиький начіональний технічний університет \\ Літкович Юлія Вікторівна, \\ кандидат філологічних наук, стариий викладач кафедри украӥнської та іноземної лінгвістики, \\ Луиький начіональний технічний університет

\section{ВИКОРИСТАННЯ НОВІТНІХ ТЕХНОЛОГІЙ У ПРОЦЕСІ НАВЧАННЯ МАЙБУТНІХ ФІЛОЛОГІВ} \\ У статті висвітлено роль використання сучасних технологій в прочесі навчання майбутніх філологів. Розглянуто різні під- \\ ходи та методи, що можуть допомогти студентам, які вивчають іноземну мову, поліпшити свої навички навчання за допомо- \\ гою новітніх технологій. Серед иих методів є застосування інтернет-сайтів з вивчення іноземної мови, комп 'ютерні програми \\ вивчення мови, програмне забезпечення для презентачій, електронні словники, програми для спілкування в чаті та електронної \\ почти, прослуховування CD-програвачів та навчання з використання відеороликів. \\ Ключові слова: новітні технології, підходи та методи, комп 'ютерні програми, електронні ресурси, знання, інформація. \\ Oksana Smal, \\ PhD, Head of Ukrainian and Foreign Linguistics Department, Lutsk National Technical University \\ Angelika Yanovets, \\ PhD, Associate Professor of Ukrainian and Foreign Linguistics Department, Lutsk National Technical University \\ Yuliya Litkovych, \\ PhD, Senior Lecturer of Ukrainian and Foreign Linguistics Department, Lutsk National Technical University
}

\title{
MODERN TECHNOLOGY APPLICATION IN TEACHING PHILOLOGISTS
}

We live in the digital age where all the students are surrounded by different modern gadgets. Their life is full of telephones, computers, social media, messages etc. The long-term practice of teaching a foreign language proves that teaching with traditional technologies does not allow developing key, basic competencies in a particular academic discipline, so a drastic reorganization of the educational process is needed. Modern and advanced lecturers don't stay on the same place. They visit other universities for the exchange of their knowledge and experience, go to different advanced training cources, study new teaching programmes and methods in order to make their classes interesting, interactive and multifarious.

This article aims to highlight the role of using modern technology in teaching philologists. It discusses different approaches and techniques which can assist foreign language students to improve their learning skills by using new programmes, tools and methods. Among these techniques are online foreign language learning websites, computer assisted language learning programmes, presentation software, electronic dictionaries, chatting and e-mail messaging programmes, listening CD-players, and learning videos.

This article therefore is an overview presentation of how modern technologies can be in the role of assistants to both lecturers and students.

Key words: modern technologies, approaches and techniques, computer programmes, electronic resources, knowledge, data.

Постановка наукової проблеми та її значення. У світі, в якому ми з вами живемо, освіта відіграє важливу і провідну роль, а також є опорою життєдіяльності людини, ii «майбутнім». Для сучасного суспільства впровадження інноваційних технологій у навчальний процес майбутніх філологів має як теоретичне, так і практичне значення. В умовах глобалізації воно стосується перспектив, які пов'язані з так званими «високими технологіями».

Мета і завдання статті, використовуючи сучасні технології у вивченні іноземної мови, показати, як сучасні гаджети можуть бути ефективно використані для підвищення якості навчання студентів-філологів, формування та розвитку їх комунікативної культури, навчання оволодіння іноземною мовою.

Виклад основного матеріалу й обгрунтування отриманих результатів дослідження. У цей «цифровий вік» студенти з усіх боків оточені різноманітними новітніми технологіями. Від соціальних медіа до текстових повідомлень, їх особисте життя обертається навколо своїх телефонів і комп'ютерів. Крім того, робота у вищих навчальних закладах стає все більш «цифровою», оскільки університети намагаються зменшити обсяг паперових носіїв та збільшити свою увагу на впровадження технологій для підвищення академічного досвіду. Хоча, технології ніколи не повинні замінювати офіційне навчання, проте вони можуть бути цінним інструментом для досягнення студентами успіху у вивченні іноземних мов.

Поняття «навички навчання» стосується управління та організації часу, матеріалів та інформації. Тематика варіюється від управління часом та організації до використання конкретних стратегій для розуміння матеріалу. Інструкція з вивчення навичок може включати фізичну організацію матеріалів, а також організацію інформації за допомогою шаблонів записів. Крім того, локалізація основної ідеї, диференціація деталей та пошук мети - це саме ті навички навчання, які необхідні майбутнім філологам для розуміння матеріалу під час пари. Поряд з грамотністю, навички навчання є найважливішим ком- 
понентом академічного знання. Студенти повинні адаптувати стратегії відповідно до своїх потреб у навчанні таким чином, щоб вони могли розуміти, організовувати та готувати матеріали, а також правильно управляти своїм часом.

Використання новітніх технологій у процесі мовної підготовки - це не тільки нові технічні засоби, а й нові форми та методи навчання, нові підходи.

Швидке зростання інформаційно-комунікаційних технологій, яким володіють технологічно розвинені країни світу, допомагають подолати деякі бар'єри у викладанні та навчанні. Застосування сучасних технологій у сфері представлення знань може дозволити викладачам та студентам переглядати, аналізувати, критикувати та перефразовувати питання, що мають логічний та контекстуальний характер. Сьогодні, такі нові технології, як, наприклад, комп'ютерні програми доведені до удосконалення з новим програмним забезпеченням і мережею, значно полегшують освітянам завойовувати світовий простір і економити час. Тепер ми можемо проводити навчальний процес практично в будь-якому місці на Землі, в будьякий час, з метою досягнення бажаних результатів.

Важко перерахувати та схарактеризувати всі інноваційні технології, які вже існують та використовуються у світовій практиці у навчальному процесі, тому ми зупинимось на найбільш поширених, ефективних та доступних серед викладачів та студентів.

Сьогодні не можливо уявити навчальний процес без застосування комп'ютера та комп'ютерної техніки. Викладачі використовують ці засоби для швидкого введення інформації при створенні простих навчальних програм у вигляді вправ, що застосовують для перевірки знань студентів. Технічна перевага викладання іноземної мови за допомогою мультимедійних технологій полягає в тому, що звукові карти дозволяють користувачам записувати їхню мову, а потім порівнювати їі з вимовою носіїв мови [1, p. 134]. Графічні можливості комп’ютерів можуть представляти будь-який вид діяльності у вигляді малюнків або анімації. Це особливо важливо при вивченні нової лексики, оскільки зображення на моніторі дозволяють студентам-філологам безпосередньо пов'язувати фрази з діями, а не 3 фразами рідною мовою. Крім того, засоби масової інформації є відмінним засобом інтерактивного спілкування між різними мовними групами, що особливо очевидно в застосуванні комп'ютерних мереж. Це може бути локальна мережа, що з'єднує кілька комп'ютерів в одному навчальному закладі, оскільки Інтернет - глобальна мережа мільйонів користувачів [2, p. 181].

Науковцями доведено, що за допомогою відео та аудіо матеріалів людина запам’ятовує до 80\% інформації.

Мультимедійні технології мають ряд переваг перед інформаційними. Студенти не можуть підтримувати та покращувати свої мовні навички лише за допомогою підручників, вони потребують постійного вдосконалення - використання автентичних джерел. Важливим фактором при вивченні іноземної мови є прослуховування текстів, фраз та діалогів саме носіїв мови, що дасть кращу можливість запам'ятовування нових виразів, граматичних конструкцій тощо.

На наступному місці є використання, як викладачами так і студентами різноманітних навчальних сайтів: Quizlet, FluentU, Socrative та інших.

Quizlet-це потужна та гнучка онлайн-платформа для навчання, заснована на використанні інструменту запам'ятовування: флеш-карти. “Набори” цифрових карт можуть бути використані для збагачення словникового запасу студентів, а також добре працюють для вивчення граматичних тем, таких як рід або дієвідміна дієслова тощо. Викладачі можуть створювати та організовувати такі “набори” цифрових карт із завданнями для своїх занять, а також стежити за їх виконанням та прогресом на певному етапі. Студенти, у свою чергу, мають доступ до величезного архіву “наборів” цих карт і можуть легко шукати різні теми, або переглядати необхідну лексику до неї. Виконання таких вправ є цікавим та захоплюючим, з великою кількістю можливостей для роботи в парах. Загалом, це чудовий інструмент для домашнього завдання і для роботи на парі.

Fluent $U$ - це ще один із навчальних сайтів, що використовується викладачами-філологами під час пар та у поза аудиторний час для вивчення студентами нового вокабуляру у веселій, дружній, повністю доступній для них формі. Цей освітній сайт дозволяє вивчати мову за допомогою автентичних матеріалів, таких як новини, музичні кліпи та трейлери до фільмів, рекламні ролики, політичні переговори, мультфільми. Перевага цього сайту в тому, що весь матеріал є актуальним, змістовним і цікавим для сучасних студентів, які хочуть вивчити іноземну мову.

3 появою передових технологій та Інтернету, використання комп'ютерів у навчанні мови забезпечує автентичне середовище для спілкування студентів з носіями мови в не витратний спосіб.

3 FluentU студенти вивчають мову, долають розмовний бар'єр. Вони мають можливість почути нові слова у контексті, а не у вигляді “вирваних фрагментів”. Кожен філолог гарантовано знайде своє відео, яке йому до вподоби дивитися, а викладач гарантовано підбере таке, що підходить по тематиці до теми заняття.

FluentU має виділені інтерактивні заголовки, які дозволяють натискати будь-яке слово, щоб побачити зображення, визначення, аудіо та корисні приклади. Тепер почути носіїв мови легко і доступно для будь-якого студента, на будь-якому рівні кваліфікації, завдяки інтерактивним транскриптам.

Наступним інструментом при вивченні іноземних мов є застосування Collaborative Tools, або “засобів взаємодіï”.

Вивчення мови є повноцінним тільки тоді, коли майбутній філолог окрім спілкування вміє ще й використовувати мову на письмі. Ось деякі інструменти, які допоможуть студентам працювати в парах: Google документи, Facebook, блоги та iн.

Якщо в аудиторії немає можливості працювати з інтерактивними дошками, то використання документів Gоogle може бути корисним інструментом для спільної роботи. Викладач може завантажувати свій Google диск із великою кількістю завдань в аудиторії. Натисканням миші будь-який студент має можливість вносити відповіді при виконанні вправ. Такий вид діяльності на парі ідеально підходить для того, щоб виконувати завдання парами.

Cеред менш поширених технологій у нас в країні є використання таких додатків до планшетів та смартфонів: DuoLingo, Memrise, Lore, Study Blue та багато інших.

“Lore” в перекладі на українську “традиційні практичні знання”. Цей новий стартап використовує платформу типу Facebook, яка працює як освітня. Ця соціальна мережа дозволяє викладачам і студентам спілкуватися, висловлюючи свої думки з приводу різних питань, стежити за роботою один одного, обговорювати аудиторні заняття і лекції в мережі.

Додатково до соціального аспекту, вона дозволяє завантажувати документи, обмінюватися розкладами та містить таку опцію, як “залікова книга”. Це краще ніж Facebook. Оскільки соціальні мережі не завжди є найкращим місцем для розви- 
тку академічних мереж. Студенти можуть прослідковувати завантаження своїми викладачами нових вправ, текстів, відео та аудіо завдань і взаємодіяти з ними.

Нині молодь все більше використовує свої смартфони як основне джерело для навчальних матеріалів. Програма “Study Blue" дозволяє студентам організовувати свої курсові роботи, зберігати нотатки на карту пам'яті та ділитися своїми матеріалами з іншими студентами.

Головною перевагою "Study Blue" є мобільність. Незалежно від того, стоїть студент в черзі за кавою, їде в поїзді або чекає зубного лікаря, він може легко отримати доступ до занять в аудиторії та підготуватися до іспиту. Соціальний аспект допомагає студентам знаходити інших людей, які вивчають подібні предмети, використовувати при цьому їхні нотатки та навчальні посібники.

“Flipped Classroom” в перекладі на українську “змішаний онлайн та офлайн режим” ще один з інноваційних методів, який широко застосовується у європейських вищих навчальних закладах при вивченні іноземних мов. Ця модель навчання використовує технології, щоб змінити спосіб навчання викладачів-лекторів. Замість того, щоб витрачати час на читання лекції, лекційний матеріал надається студентам у відеоформаті, щоб вони могли переглядати його вдома.

В такий спосіб аудиторний час приділяється на допомогу кожному студенту індивідуально, обговорення та взаємодію на основі лекційного домашнього завдання. 3 майже кожним студентом, який приносить мобільний пристрій або ноутбук, ця модель представлення матеріалу може дати студентам і викладачам більше часу для роботи над труднощами, а не простою лекцією. Ми часто бачимо, що дорогоцінний час в аудиторії витрачається тоді, коли викладач записує інформацію на дошці, а тоді повертається до студентів і починає пояснювати.

Сьогодні студенти часто публікують свої мультимедійні результати у блогах, що дає їм реальну аудиторію для спільної роботи, експертну оцінку з коментарями та заохоченнями до підвищення свого рівня знань. Віртуальні навчальні середовища пропонують студентам можливості дистанційного навчання мови та покращення своїх мовних навичок, що для сучасних студентів $є$ дуже зручно. Такі інструменти, як Padlet, Popplet, Linoit i Pinterest, дозволяють студентам легко співпрацювати зі своїми колегами-однодумцями в невеликих групах, обговорюючи навчання.

Багато сучасних університетів та факультетів по вивченню іноземних мов ведуть свої власні облікові записи у Тwitter, щоб у такий спосіб підтримувати зв'язок з батьками, інформувати студентів про важливі події, про відзначення досягнень певних студентів і поширювати “твіти” про нові аспекти вивчення іноземної мови, нові слова, сталі вирази, граматичні конструкції тощо.

Сучасні технології є незамінними для індивідуального, самостійного навчання, де студенти можуть працювати в своєму власному темпі, чітко виконувати інтерактивні вправи в аудиторії або вдома і отримувати миттєвий результат. Отримання балів і можливість порівняти їх зі своїми одногрупниками мотивує і додає залучення елементів гри до їхнього навчання.

Як ми бачимо, існує необхідність у впровадженні новітніх технологій під час навчання іноземних мов не як у винагороді, чи заохоченні, а як у складовій частині навчального процесу. Завдяки такому підходу викладачі розвивають у майбутніх філологів творчі здібності, здібності вільного спілкування, співпраці та критичного мислення. Завдяки інформаційним технологіям студенти легко використовують автентичні ресурси, які сприяють міжкультурному розумінню та взаємодії 3 віртуальними колегами в реальному контексті.

Висновки та перспективи подальших розвідок. Живучи в сучасному світі, викладачі також змушені самоудосконалюватися, проходити різноманітні тренінги, вивчати нові програми та методики, їздити на стажування задля обміну досвідом, щоб не перетворювати використання цифрових засобів масової інформації на проблему і щоб заохочувати студентів до вивчення іноземних мов.

Що стосується практичного застосування перерахованих вище технологій, то не потрібно застосовувати на практиці тільки одну з них. Краще інтегрувати декілька, об'єднавши при цьому їх найкращі аспекти. Застосування саме таких новітніх технологій у процесі мовної підготовки сприяє розкриттю суб'єктивного досвіду студента, формуванню особистісноосмислених шляхів навчання, вихованню моральних ідеалів, розвитку критичного мислення, адекватної оцінки та самостійності, самовдосконаленню кожного студента і можливість реалізувати себе як особистість.

Більше того, сучасні студенти знайомі зі способом збору корисної інформації та матеріалів, оскільки сьогодні більшість 3 них використовує такі пристрої, як смартфони, комп'ютери та планшети вдома. Студенти більше прагнуть вчитися, і вони можуть залишатися зосередженими довше під час занять, оскільки різноманітність доступних матеріалів заважає студентам відчувати монотонність і нудьгу. Крім того, їх сфера інтересів розширюється в результаті впливу на різні сфери та аспекти життя. Їх навчальний процес стає більш ефективним і самостійним. Переглядаючи Інтернет вдома, студенти розвивають власний темп вивчення мови й використовують додаткові навчальні платформи, які допомагають їм вдосконалювати свої знання мови.

Отже, використання засобів масової інформації разом із новітніми технологіями може бути відмінним інструментом для навчання іноземної мови. Використання таких пристроїв не відкидає традиційних методів і не заперечує їх ефективність, а підтримує і вдосконалює весь процес викладання і навчання, пропонуючи його альтернативні форми. Завдяки використанню викладачем мультимедіа, заняття з вивчення іноземної мови стають більш динамічними та цікавими, що робить заняття більш ефективними та приємними. Однак реалізація таких вправ залежить від наявності електронних пристроїв в аудиторіях. На жаль, не всі вищі навчальні заклади нашої країни можуть похизуватися обладнаними мультимедіа аудиторіями і це певним чином заважає викладачам застосовувати різні новітні технології та програми у навчальному процесі.

\section{Лiтература:}

1. Robert I. V. Modern information technologies in education. Moscow : Moscow School Press, 1994. 215 p.

2. Yang L. R. Benefits and drawbacks of controlled laboratory studies of second language acquisition. Cambridge : Cambridge University Press, 2001. P. 173-193.

3. URL: www.theguardian.com/teacher-network/2014/may/13/ modern-foreign-languages-technology-tools-students-fluent.

4. URL: www.teachthought.com/technology/15-examples-of-new-technology. 